\title{
Half a degree additional warming, prognosis and projected impacts (HAPPI): background and experimental design
}

\author{
Daniel Mitchell $^{1, a}$, Krishna AchutaRao ${ }^{2}$, Myles Allen $^{1,3}$, Ingo Bethke ${ }^{4}$, Urs Beyerle ${ }^{5}$, Andrew Ciavarella ${ }^{6}$,

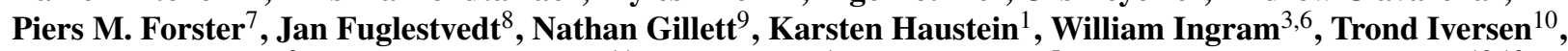 \\ Viatcheslav Kharin $^{9}$, Nicholas Klingaman ${ }^{11}$, Neil Massey ${ }^{1}$, Erich Fischer ${ }^{5}$, Carl-Friedrich Schleussner ${ }^{12,13}$, \\ John Scinocca $^{9}$, Øyvind Seland ${ }^{10}$, Hideo Shiogama ${ }^{14}$, Emily Shuckburgh ${ }^{15}$, Sarah Sparrow ${ }^{16}$, Dáithí Stone ${ }^{17}$, \\ Peter Uhe $^{16,1}$, David Wallom ${ }^{16}$, Michael Wehner ${ }^{17}$, and Rashyd Zaaboul ${ }^{18}$ \\ ${ }^{1}$ Environmental Change Institute, School of Geography and the Environment, Oxford University, Oxford, UK \\ ${ }^{2}$ Centre for Atmospheric Sciences, Indian Institute of Technology Delhi, New Delhi 110016, India \\ ${ }^{3}$ Atmospheric, Oceanic and Planetary Physics (AOPP), Oxford University, Oxford, UK \\ ${ }^{4}$ Uni Research Climate, Bjerknes Centre for Climate Research, Bergen, Norway \\ ${ }^{5}$ ETH Zurich, Institute for Atmospheric and Climate Science, Zurich, Switzerland \\ ${ }^{6}$ Met Office Hadley Centre for Climate Science and Services, Exeter, UK \\ ${ }^{7}$ School of Earth and Environment, University of Leeds, Leeds, UK \\ ${ }^{8}$ Center for International Climate and Environmental Research - Oslo (CICERO), PO Box 1129 Blindern, 0318 Oslo, Norway \\ ${ }^{9}$ Canadian Centre for Climate Modelling and Analysis, Environment and Climate Change Canada, \\ University of Victoria, Victoria, V8W 2Y2, Canada \\ ${ }^{10}$ Norwegian Meteorological Institute, Oslo, Norway \\ ${ }^{11}$ National Centre for Atmospheric Science - Climate, Department of Meteorology, University of Reading, Reading, UK \\ ${ }^{12}$ Climate Analytics, Berlin, Germany \\ ${ }^{13}$ Potsdam Institute for Climate Impact Research, Potsdam, Germany \\ ${ }^{14}$ Center for Global Environmental Research, National Institute for Environmental Studies, 16-2 Onogawa, \\ Tsukuba, Ibaraki 305-8506, Japan \\ ${ }^{15}$ British Antarctic Survey (BAS), High Cross, Madingley Road, Cambridge, UK \\ ${ }^{16}$ Oxford e-Research Centre (OeRC), University of Oxford, Oxford, UK \\ ${ }^{17}$ Lawrence Berkeley National Laboratory, Berkeley, CA, USA \\ ${ }^{18}$ International Center for Biosaline Agriculture, P.O. Box 14660 Dubai, UAE \\ ${ }^{a}$ now at: School of Geographical Sciences, University of Bristol, Bristol, UK
}

Correspondence to: Daniel Mitchell (mitchell@atm.ox.ac.uk)

Received: 28 July 2016 - Discussion started: 24 August 2016

Revised: 16 December 2016 - Accepted: 4 January 2017 - Published: 8 February 2017

\begin{abstract}
The Intergovernmental Panel on Climate Change (IPCC) has accepted the invitation from the UNFCCC to provide a special report on the impacts of global warming of $1.5^{\circ} \mathrm{C}$ above pre-industrial levels and on related global greenhouse-gas emission pathways. Many current experiments in, for example, the Coupled Model Inter-comparison Project (CMIP), are not specifically designed for informing this report. Here, we document the design of the half a degree additional warming, projections, prognosis and im-
\end{abstract}

pacts (HAPPI) experiment. HAPPI provides a framework for the generation of climate data describing how the climate, and in particular extreme weather, might differ from the present day in worlds that are 1.5 and $2.0^{\circ} \mathrm{C}$ warmer than pre-industrial conditions. Output from participating climate models includes variables frequently used by a range of impact models. The key challenge is to separate the impact of an additional approximately half degree of warming from uncertainty in climate model responses and internal climate 
variability that dominate CMIP-style experiments under lowemission scenarios.

Large ensembles of simulations (>50 members) of atmosphere-only models for three time slices are proposed, each a decade in length: the first being the most recent observed 10-year period (2006-2015), the second two being estimates of a similar decade but under 1.5 and $2{ }^{\circ} \mathrm{C}$ conditions a century in the future. We use the representative concentration pathway 2.6 (RCP2.6) to provide the model boundary conditions for the $1.5^{\circ} \mathrm{C}$ scenario, and a weighted combination of RCP2.6 and RCP4.5 for the $2{ }^{\circ} \mathrm{C}$ scenario.

\section{Introduction}

In its Paris Agreement, the parties of the United Nations Framework Convention on Climate Change (UNFCCC) have established a long-term temperature goal for climate protection of "holding the increase in the global average temperature to well below $2{ }^{\circ} \mathrm{C}$ above pre-industrial levels and pursuing efforts to limit the temperature increase to $1.5^{\circ} \mathrm{C}$ above pre-industrial levels, recognising that this would significantly reduce the risks and impacts of climate change" (UNFCCC, 2015). Such an agreement has naturally received interest from the academic community, with numerous authors commenting on this outcome (e.g. Hulme, 2016; Peters, 2016; Rogelj and Knutti, 2016; Mitchell et al., 2016b; Anderson and Nevins, 2016; Boucher et al., 2016; Schleussner et al., 2016). However, the body of research assessing impacts under a $1.5^{\circ} \mathrm{C}$ world is small compared to higher emission scenario studies (James et al., 2017), though there are notable exceptions (Fischer and Knutti, 2015; Schleussner et al., 2016). It has been argued that current coordinated international climate modelling experiments, such as the Coupled Model Intercomparison Project (CMIP5) (Taylor et al., 2012), may not be best suited to address this question, and so we need dedicated climate experiments (Mitchell et al., 2016b).

HAPPI is proposed to provide a framework to assess the impacts of a $1.5^{\circ} \mathrm{C}$ world, and the impacts avoided from higher degree worlds, such as $2^{\circ} \mathrm{C}$. As argued in Mitchell et al. (2016b), assessment of the impacts of a $1.5^{\circ} \mathrm{C}$ world requires large sets of simulations in order to adequately sample the extreme weather that often is associated with the highest climate-related impacts and risks, and it also requires simulations under steady forcing conditions in order to address the $1.5^{\circ} \mathrm{C}$ target. Figure 1 shows a schematic of how HAPPI differs from scenario-based approaches, such as CMIP. The more traditional scenario-based approach (top panel) starts with either an emission scenario, such as those used in CMIP3 (Special Report on Emissions Scenarios; SRES) (Nakicenovic and Swart, 2000), or a pathway to reach a certain radiative forcing by 2100 , such as those used in CMIP5 (representative concentration pathway; RCP) (Van Vuuren et al.,
2011). As uncertainty increases with time, and is dominated by responses and variability in CMIP-style experiments, as illustrated in Fig. 1 (upper panel), such experiments are not ideal to inform assessments of impacts at specific levels of warming such as 1.5 or $2{ }^{\circ} \mathrm{C}$, let alone the difference between two such warming levels. For example, the lowest CMIP5 scenario, the RCP2.6, shows a median global-mean temperature increase of $1^{\circ} \mathrm{C}$ above $1986-2005$ levels, with a likely range between 0.3 and $1.7^{\circ} \mathrm{C}$ over the CMIP5 model ensemble (Collins et al., 2013). This range includes 1.5 and $2{ }^{\circ} \mathrm{C}$ warming above pre-industrial levels, which introduces some issues into the assessment of differences in impacts of these warming levels based on such a model ensemble. Some studies have used methodologies with CMIP5 models that partially address this issue, for instance Fischer and Knutti (2015) pick 20 year periods from transient simulations centred on a specific global-mean temperature threshold. Such a method has advantages over the HAPPI method in that it taps into the wealth of model integrations already performed in CMIP, but also that it samples SST variability across the board (the atmospheric models are coupled to interactive oceans $)^{1}$. However, it also adds an extra level of complexity in that there is a large spread in timing for when transient CMIP models cross $1.5^{\circ} \mathrm{C}$, and different forcings will be at play during different times. One example is ozonehole recovery and the implications for Southern Hemisphere circulation patterns, which are likely to be different if, for example, a model crosses $1.5^{\circ} \mathrm{C}$ in 2030 rather than 2050 (e.g. Son et al., 2010). It is also harder to calculate a robust return period from transient simulations, because contiguous data will only be consistent with a global-mean temperature threshold for a short period of time.

The parties of the UNFCCC have chosen to frame their goals for climate protection in terms of a global temperature response, rather than an emission scenario. As such, the UNFCCC is not asking for the risks associated with emission scenarios that is "likely" to maintain temperatures below $1.5^{\circ} \mathrm{C}$ (or some other criterion): it is asking about the risks associated with $1.5^{\circ} \mathrm{C}$ warming per se, irrespective of what emission path is followed to achieve it (emission paths being addressed in the second challenge). As such, the global response is where the HAPPI design starts, tracing through to regional extreme weather and potential impacts.

\section{Experimental design}

The experiments under HAPPI are designed to be as similar as possible in experimental design as current (or proposed) climate experiments, notably the International CLIVAR Climate of the 20th Century Plus Detection and Attribution (C20C+ D\&A) project (Gillett et al., 2016; Folland et al., 2014). Synergies between the experiments allow

\footnotetext{
${ }^{1}$ This is explicitly addressed in Sect. 2 as a sensitivity test to the HAPPI design.
} 
The emissions scenario approach
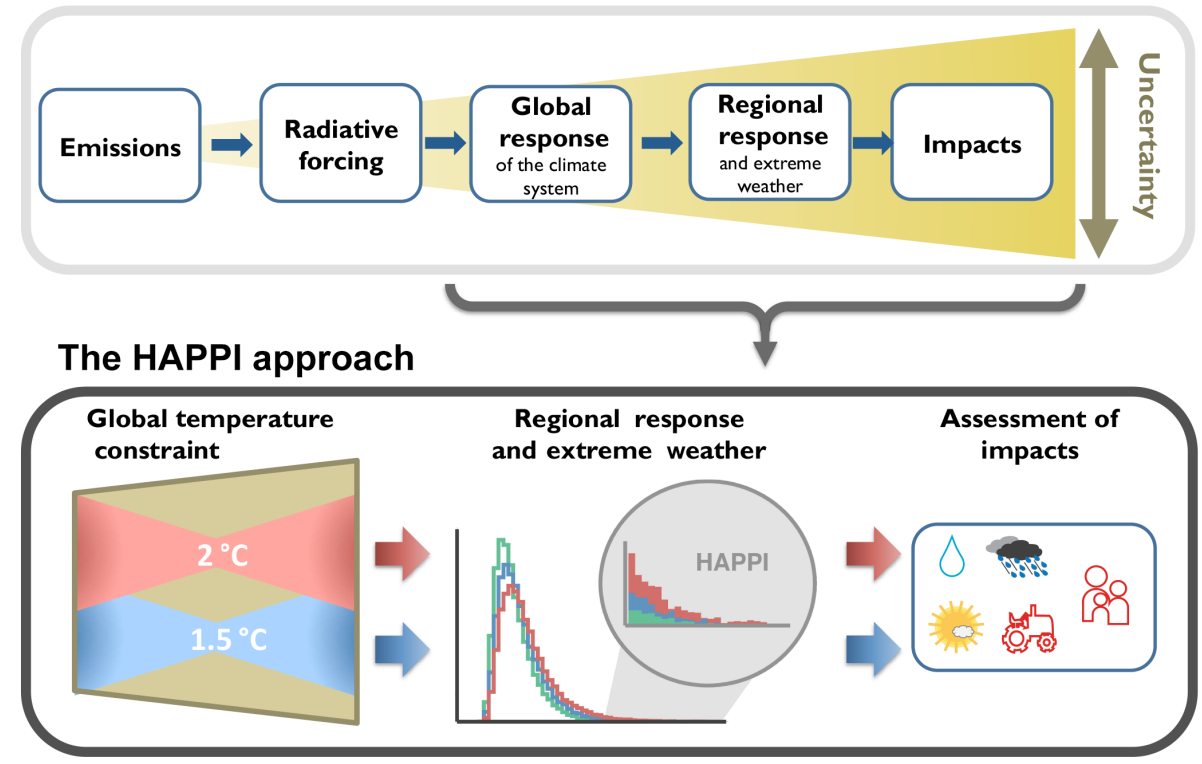

Figure 1. A schematic comparing the emission-scenario-based approaches (top), such as CMIP, with the HAPPI approach (bottom). The HAPPI approach flows from the constraint on global temperatures to the comparison of extremes using the large-ensemble approach to impact models. The histogram depicts an illustrative example of distributions for extreme-event indicators (such as maximum daily temperature) for the present day (green), $1.5^{\circ} \mathrm{C}$ (blue) and $2^{\circ} \mathrm{C}$ (red) above pre-industrial levels.

Table 1. Table of models that will likely contribute to HAPPI, with specifications and expected number of simulated model years per experiment tier. Regional climate models (RCMs) are also listed. In addition to the simulations detailed here, modelling centres will run five ensemble members of 1959 to 2015 conditions for bias-correction purposes.

\begin{tabular}{llrrrl}
\hline Model & $\begin{array}{l}\text { Horizontal } \\
\text { resolution }\end{array}$ & Tier 1 & Tier 2 & RCM & References \\
\hline CAM4 & $2 \times 2^{\circ}$ & 15000 & 0 & $\mathrm{~N}$ & Neale et al. (2013) \\
CAM5.1.2-0.25degree & $25 \times 25 \mathrm{~km}$ & 150 & 0 & $\mathrm{~N}$ & Wehner et al. (2014) \\
CAM5.1-1degree & $1.25 \times 0.94^{\circ}$ & 3000 & 6000 & $\mathrm{~N}$ & Neale et al. (2010) \\
CanAM4 & T63 & 1500 & 0 & $\mathrm{~N}$ & von Salzen et al. (2013) \\
HadAM3P & $1.88 \times 1.25^{\circ}$ & 30000 & 30000 & $\mathrm{Y}$ & Massey et al. (2014) \\
HadGEM3 & N216 & 1500 & 0 & $\mathrm{~N}$ & Walters et al. (2016) \\
MetUM-GOML2 & $1.875 \times 1.25^{\circ}$ & 0 & 450 & $\mathrm{~N}$ & Hirons et al. (2015) \\
& & & & & Walters et al. (2016) \\
MIROC5 & $150 \times 150 \mathrm{~km}$ & 3000 & 0 & $\mathrm{~N}$ & Shiogama et al. (2014) \\
MPI-ECHAM6.3 & T63 & 3000 & 0 & $\mathrm{Y}$ & - \\
NorESM1_Happi & $1.25 \times 0.94^{\circ}$ & 3750 & 2000 & $\mathrm{~N}$ & Bentsen et al. (2013) \\
& & & & & Kirkevåg et al. (2013) \\
& & & & & Iversen et al. (2013) \\
\hline
\end{tabular}

to minimise the additional computational time required from modelling centres. The core experiments will be driven with a spectrum of different leading atmosphere-only Global Circulation Models (GCMs), the initial participants of which are listed in Table 1. By using atmosphere-only models instead of fully coupled models, we are able to generate larger ensemble sizes (due to decreased computational cost) while providing more accurate regional climate projections (He and Soden, 2016). Boundary conditions for the models are taken from the CMIP5 experimental design and from models that participated in that initiative.

There are two tiers of experiments, intended to characterise various climate scenarios, as well as uncertainties in the specifications of the temperature-based scenarios.

\subsection{Tier 1 experiments}

Three core experiments are proposed: 


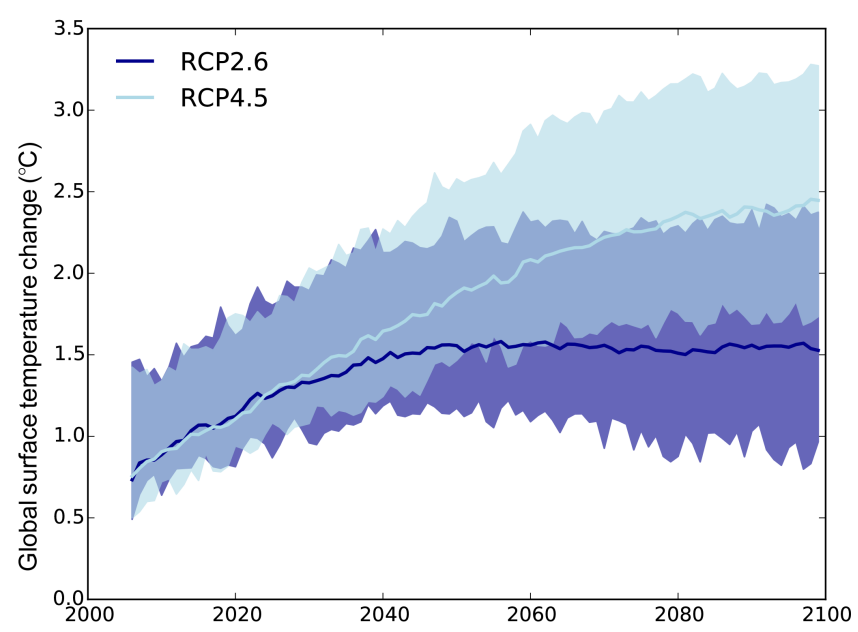

Figure 2. Time series of global annual mean surface-air temperature anomalies (relative to 1861-1880) from CMIP5 RCP2.6 and RCP4.5 experiments. Solid lines show the multi-model mean and shaded regions show the 5-95\% range across all 26 models. Only one simulation is used for each model. All models where the data were available for both scenarios were used, leading to 26 models in total.

1. Current decade (2006-2015) conditions (50- to 100member ensembles).

2. $1.5^{\circ} \mathrm{C}$ warmer than pre-industrial (1861-1880) conditions (50- to 100-member ensembles) relevant for the 2106-2115 period.

3. $2.0^{\circ} \mathrm{C}$ warmer than pre-industrial (1861-1880) conditions (50- to 100 -member ensembles) relevant for the 2106-2115 period.

Each simulation within an experiment differs from the others in its initial weather state. The use of 50-100 10 year time slices provides 500-1000 years of data per experiment. Simulations are limited to 10 years in length because the observed ocean temperatures, upon which all HAPPI experiments are based, have been approximately constant during this period (at least within the context of the anthropogenic warming scales considered by HAPPI). However, 10 year periods should provide material for some analysis of multi-year events, such as droughts. The degree to which the output of the simulations can be used to estimate unbiased return values for a specific return period will depend on various aspects of the event, such as region and climate variables. In the extratropical summer, for instance, the 500-1000 years may be considered an unbiased sample, whereas in the tropics it may be important to acknowledge the major El Niño and La Niña events during the 2006-2015 period.

Current decade experiment: Modelling centres will use observed forcing conditions as in the DECK AMIP design, including Sea Surface Temperatures (SSTs) and sea ice (Taylor et al., 2012). The 2006-2015 decade is chosen because it is our most recently observed period, but also because it contains a range of different SST patterns over the decade, allowing for an assessment of how the ocean conditions vary on inter-annual timescales. From 2017 onward, modelling centres will also have the option of simulating observed 2016 climate, thereby capturing the large El Niño event in 20152016. Note that the $\mathrm{C} 20 \mathrm{C}$ project will also perform these experiments.

The $1.5^{\circ} \mathrm{C}$ experiment: It is difficult (without many climate-model-specific iterations) to explicitly design an emissions scenario that would lead to a world exactly $1.5^{\circ} \mathrm{C}$ warmer than pre-industrial conditions. This is because the CMIP community are set up to use particular emission scenarios or RCP scenarios, rather than a scenario that leads to some chosen amount of warming. Here, we take $1.5^{\circ} \mathrm{C}$ to mean " $1.5^{\circ} \mathrm{C}$ as measured as the near-surface air temperature", as is the formal definition of the transient climate response, rather than some mix of measuring systems (for instance surface ocean) that may have implications for the energy budget (Richardson et al., 2016).

By chance, the multi-model average across climate model simulations submitted to CMIP5 under the RCP2.6 forcing scenario results in a global average temperature response at $1.55^{\circ} \mathrm{C}$ relative to pre-industrial levels (2091-2100 relative to 1861-1880). Figure 2 shows the average and 5-95\% spread in global-mean temperature anomaly for all available CMIP5 models for the RCP2.6 scenario (dark blue). Within HAPPI, we assume that this amount of warming is sufficiently close to inform the call of the UNFCCC on a special report on the "impacts of global warming of $1.5^{\circ} \mathrm{C}$ above preindustrial levels" (UNFCCC, 2015), and thus HAPPI adopts the end-of-century anthropogenic radiative forcing conditions from the RCP2.6 emissions scenario. Specifically, forcing values for the year 2095 for greenhouse gases, aerosol, land-use, and land-cover changes are repeated for each of the years within the $1.5^{\circ} \mathrm{C}$ decade. Natural radiative forcings, however, are set to the same values as in the current-decade experiment.

Projected SSTs are calculated by adding to the observed 2006-2015 SSTs a change in SST $(\Delta$ SST) between the decadal average of the modelled 2006-2015 period and the decadal average of the modelled $1.5^{\circ} \mathrm{C}$ world over 2091-2100. Hence the SST patterns are still timevarying because they are based on the 2006-2015 observations, but they have an additional warming added to them. As CMIP5 historical simulations stopped in 2005 , the decadal average of the 2005-2015 SSTs is estimated from RCP8.5 simulations, as this is the scenario that is closest to observations over this period. 

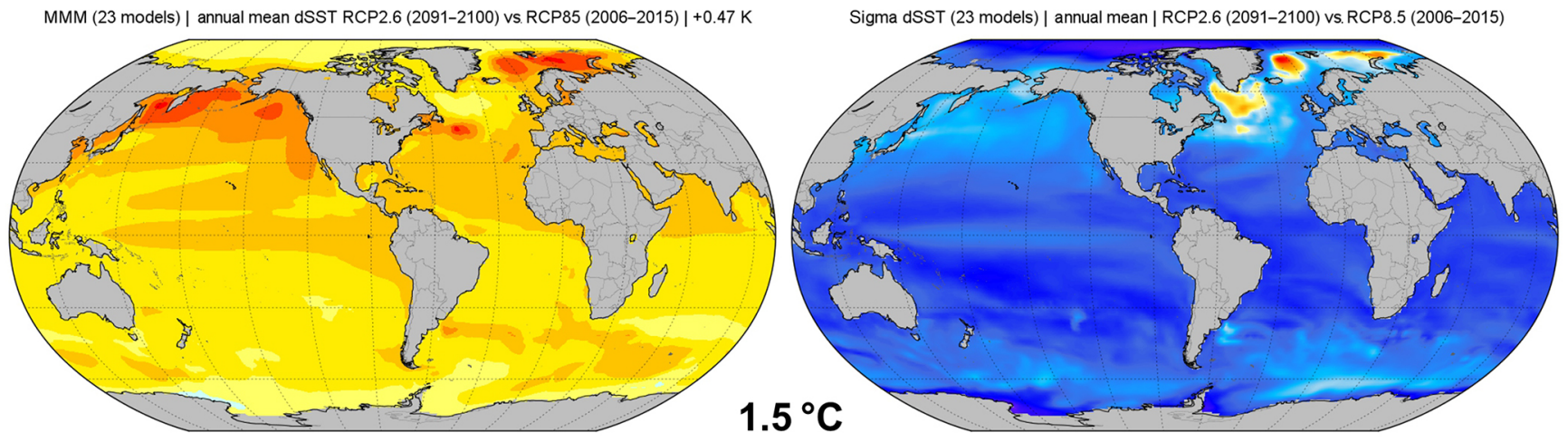

MMM (23 models) | annual mean dSST RCP2.6/4.5 (2091-2100) vs. RCP85 (2006-2015) | +0.81 K

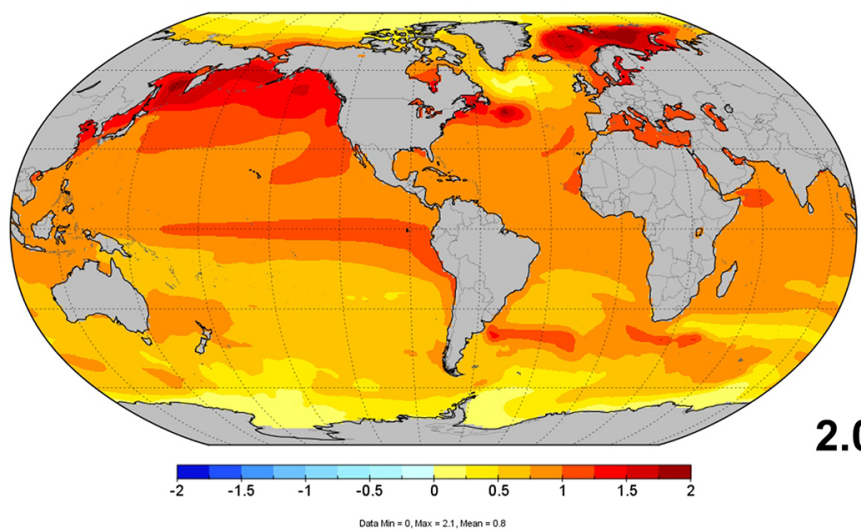

Sigma dSST (23 models) | annual mean | RCP2.6/4.5 (2091-2100) vs. RCP8.5 (2006-2015)

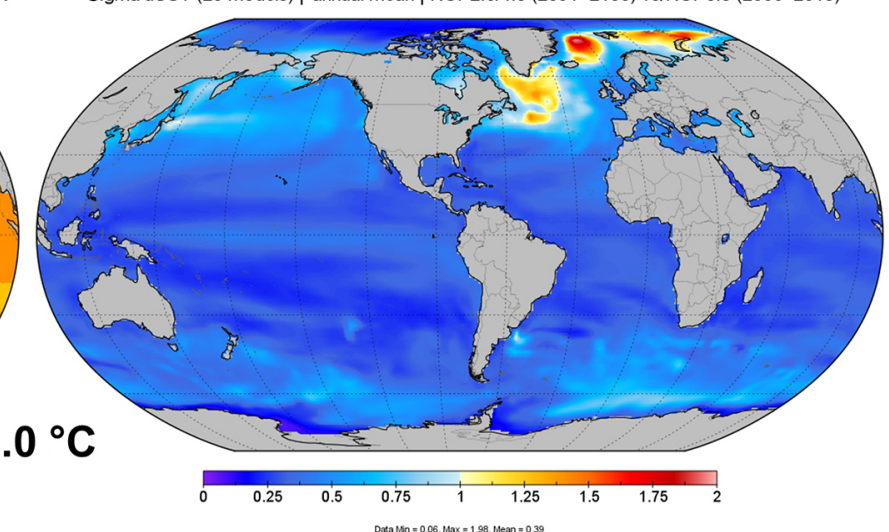

Figure 3. Left: SST warming pattern added to the current decade to produce the (top) $1.5^{\circ}$ and (bottom) $2^{\circ}$ scenarios. Right: the standard deviation of annual mean delta SSTs across the 23 models. Units are in ${ }^{\circ} \mathrm{C}$.

The decadal average of the 2091-2100 SSTs is estimated from CMIP5 RCP2.6 simulations. The spread of these models is shown in Fig. 2, of which 23 models have the required data (see Sect. 2.2 for more details on the individual patterns). The resulting multi-model average $\Delta$ SST, used in the $1.5^{\circ} \mathrm{C}$ experiment, is shown in Fig. 3. The global-mean SST response is $1.02^{\circ} \mathrm{C}$ relative to the pre-industrial period, with larger warming over land providing the global $1.55^{\circ} \mathrm{C}$ total. Because of the time period we use as our baseline (2006-2015) some of the so-called hiatus effect may bias our results cold, and this will be partially compensated for by the fact that our global-mean temperature is $0.05^{\circ} \mathrm{C}$ higher than desired, but we also note that it is the difference between the $0.5^{\circ} \mathrm{C}$ warming in these relatively low emission scenarios that is important, rather than the exact magnitude.

Estimated sea ice is more problematic than estimated SSTs, because the CMIP-projected Arctic and Antarctic sea ice extents vary dramatically between models (Collins et al., 2013). In the Arctic, most climate models show a decrease at all longitudes in sea ice. In the Antarctic, the overall model responses show a similar decrease with equally variable projections. The
CMIP5 climate models are also unable to capture the observed increases in Antarctic sea ice over the satellite era (Turner et al., 2013), leading to low confidence in their ability to predict future changes. As such, we use a different method to estimate sea ice under $1.5^{\circ} \mathrm{C}$ and higher scenarios, which is an adaptation of Massey (2017). In short, we calculate an anomaly (from 1996 to 2015) for every month from 1996 to 2015 in both SSTs and sea ice from the operational sea surface temperature and sea ice analysis (OSTIA) data set (Stark et al., 2007) and fit a linear relationship between SSTs and sea ice as a function of month and grid box. We use as the regressor the meridional average of SST grid boxes, within a hemisphere, at grid points where there is ice present at some point in time between 1996 and 2015 (i.e. the climatological monthly mean ice concentration for the grid box is non-zero). This represents temperature at that longitude under and near the ice edge, thereby minimising poorly observed values in ice-covered regions. We use ice cover in an index grid box as the regressand, and smooth the resultant field with a $500 \mathrm{~km}$ smoother. We then apply the sea ice-SST relationship to the $1.5^{\circ} \mathrm{C}$ experiment SST anomalies, to give a projected sea ice concentration anomaly. These anomalies are added on 
(a) NH SIC HAPPI average

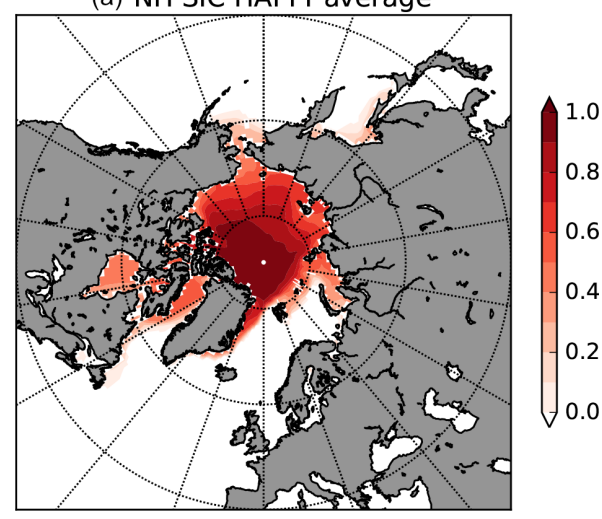

(c) NH SIC HAPPI - OSTIA

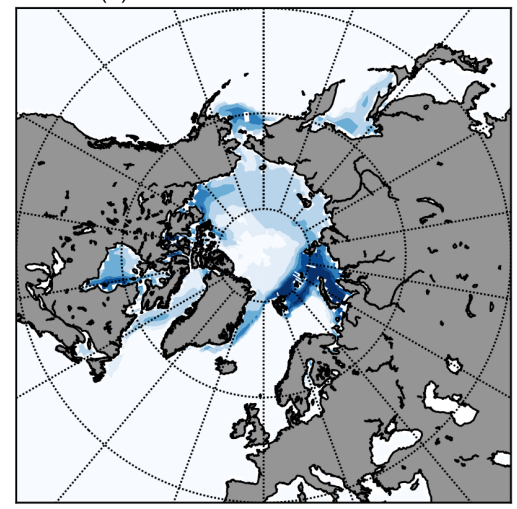

(b) SH SIC HAPPI average

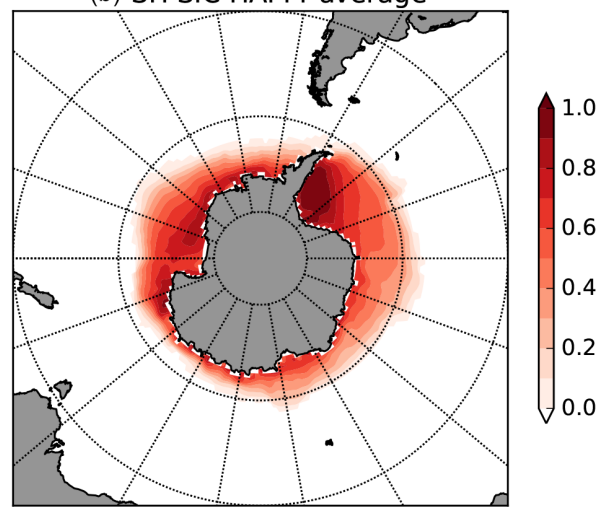

(d) SH SIC HAPPI - OSTIA

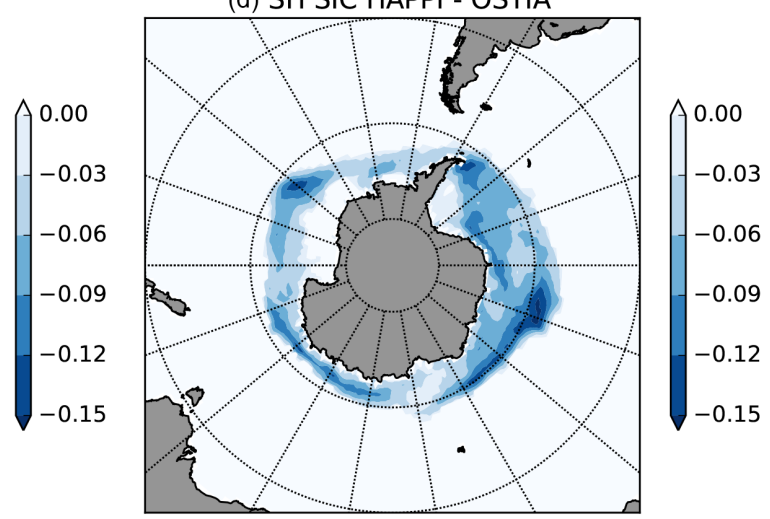

Figure 4. Polar stereographic projections of decadal-mean (top) sea ice concentration from the $1.5^{\circ}$ experiment and (bottom) the difference in sea ice concentration between the $1.5^{\circ}$ experiment and OSTIA. The OSTIA data cover the decade 2006-2015. Left panels show the Northern Hemisphere, right panels show the Southern Hemisphere.

to the observed OSTIA data spanning the most recent decade. The absolute sea ice concentration fields and anomalies from observations are given in Fig. 4. This methodology has the added benefit that the SSTs and sea ice are consistent with each other in the HAPPI experiments.

The $2{ }^{\circ} \mathrm{C}$ experiment: For the $2{ }^{\circ} \mathrm{C}$ experiment, no analogous CMIP5 simulations are available. The RCP scenario resulting in the second coolest temperatures by the end of the 21 st century is RCP4.5, which reaches $\sim 2.5^{\circ} \mathrm{C}$ relative to pre-industrial levels by the end of the 21 st century (Fig. 2). Both RCP2.6 and RCP4.5 have $5-95 \%$ ranges that overlap a global mean temperature of $2{ }^{\circ} \mathrm{C}$, and the mean of both scenarios are a similar distance from this threshold.

To calculate the future SST and sea ice conditions of a $2{ }^{\circ} \mathrm{C}$ world we therefore take a weighted sum of the two RCP scenarios, $\mathrm{W}_{1} \times \mathrm{RCP} 2.6+\mathrm{W}_{2} \times \mathrm{RCP} 4.5$. The weights are calculated such that the global-mean temperature response is $2.05^{\circ} \mathrm{C}$ (i.e. exactly half a de- gree above the $1.55^{\circ} \mathrm{C}$ response from the $1.5^{\circ} \mathrm{C}$ experiment), and results in $\mathrm{W}_{1}=0.41$ and $\mathrm{W}_{2}=0.59$. These weights are used to calculate the SSTs and sea ice coverage using the same methodology as in the $1.5^{\circ} \mathrm{C} \mathrm{ex}-$ periment.

The same weightings are applied to the radiative forcing of each well-mixed greenhouse gas (e.g. $\mathrm{CO}_{2}, \mathrm{CH}_{4}$, $\mathrm{N}_{2} \mathrm{O}$, CFCs etc). Some concentrations do not scale linearly with radiative forcing, for instance $\mathrm{CO}_{2}$ concentrations following a logarithm, and the $\mathrm{CH}_{4}$ and $\mathrm{N}_{2} \mathrm{O}$ concentrations follow a square root. All other concentrations are linearly related to the radiative forcing. A full list of these relationships is given by the IPCC (AR3, 2001). Natural forcings remain at the $1.5^{\circ} \mathrm{C}$ experiment (and current-decade experiment) values. Land cover and land use are represented in a discretised form in the climate models, and so cannot be interpolated. Meanwhile, the climate responses to anthropogenic aerosols and ozone concentrations (or, for some models, emissions of their precursors) do not follow a simple functional form, and in the case of aerosols this 
is further complicated by major differences in the spatial distributions of concentrations between the two RCPs. Considering that the parties of the UNFCCC are most concerned about a $\mathrm{CO}_{2}$-dominated warming, and $\mathrm{CO}_{2}$ is the dominant contributor to changes in the radiative budget by 2100 (e.g. see Fig. 12.3 of Collins et al., 2013), we chose to set the remaining (i.e. other than $\mathrm{CO}_{2}$, SST, sea ice, and natural forcings) $2{ }^{\circ} \mathrm{C}$ experiment forcings to their $1.5^{\circ} \mathrm{C}$ experiment values.

In addition to the three core experiments, modelling centres will also run at least five ensemble members spanning the period 1959-2015, thereby allowing for a range of biases in the climate models to be assessed (see Sect. 5).

\subsection{Tier 2 experiments}

The Tier 2 experiments will replicate the Tier 11.5 and $2{ }^{\circ} \mathrm{C}$ experiments, but also take into account SST and sea ice uncertainty at the expense of ensemble size. Individual estimates of SST response patterns from the 23 different CMIP5 models will be used, the annual means of which are presented in Appendix A for both scenarios. Each individual model pattern will be scaled to have the same SST mean response as the multi-model mean (MMM) response $\left(1.02^{\circ} \mathrm{C}\right.$ for the $1.5^{\circ} \mathrm{C}$ experiment); this will give a measure of the impact of uncertainty in the pattern of large-scale warming, conditioned on a specific global temperature change, consistent with research demanded by the UNFCCC call.

Additional Tier 2 experiments will determine the sensitivity of the response to 1.5 and $2.0^{\circ} \mathrm{C}$ of warming to the inclusion of atmosphere-ocean interactions in models, and hence to the choice of an AMIP-type approach for the Tier 1 HAPPI experiments. This is an important question, given that air-sea feedbacks have been shown to affect the fidelity of model representations of key phenomena that control weather and climate extremes (e.g. the Madden-Julian oscillation; DeMott et al., 2015). These Tier 2 experiments use atmospheric GCMs coupled to either one-dimensional mixed-layer oceans (i.e. with vertical resolution) or zerodimensional slab oceans. These models require bias corrections to either the full vertical profile of temperature and salinity (for mixed-layer oceans) or to SST (for slab oceans) to represent missing ocean dynamics and to correct for biases in atmospheric surface fluxes (e.g. Hirons et al., 2015). A key advantage of these models is that they can maintain a given global-mean temperature effectively indefinitely. They do not include modes of coupled atmosphere-ocean variability that rely on ocean dynamics (e.g. the El Niño-Southern Oscillation or the Indian Ocean Dipole), which can be an advantage as it avoids issues of under-sampling natural variability. These models are also much less computationally expensive than coupled models with full ocean GCMs.

Here, we describe the experiment design for Tier 2 experiments with the MetUM-GOML2 model, which comprises the Global Atmosphere 6.0 configuration of the Met Office Unified Model (Walters et al., 2016) coupled to the MultiColumn K Profile Parameterisation mixed-layer ocean (MCKPP), as described in (Hirons et al., 2015). First, we perform a present-day ensemble using forcing for the 1976-2005 period: greenhouse gases and aerosols are set to the average values of the period 1976-2005; temperature and salinity corrections constrain MC-KPP to the ocean climatology from Smith and Murphy (2007); and climatological sea ice extent and concentrations are prescribed. Climatological SSTs are also prescribed in regions of seasonal sea ice cover in the high latitudes, where the model is not coupled (see Hirons et al., 2015). 1976-2005 differs from the 2006-2015 period chosen for the Tier 1 experiments, but the objective is to understand the effect of air-sea coupling on the response to warming, not to compare the MetUM-GOML2 present-day simulation to any other model.

Secondly, we adjust the $\mathrm{CO}_{2}$ in MetUM-GOML2 to achieve target global-mean warming levels, relative to the present-day ensemble, consistent with 1.5 and $2.0^{\circ} \mathrm{C}$ above pre-industrial levels, measured by near-surface air temperature. The target levels are computed by first finding the observed global-mean surface temperature difference between 1976-2005 and pre-industrial values, which is $0.52^{\circ} \mathrm{C}$ in HadCRUT4. The target levels are set to 1.5 and $2.0^{\circ} \mathrm{C} \mathrm{mi-}$ nus this difference, or 0.98 and $1.48^{\circ} \mathrm{C}$, respectively. This is equivalent to projecting the change between a 1.5 or $2.0^{\circ} \mathrm{C}$ warmer world and the 1976-2005 period. Finding the correct $\mathrm{CO}_{2}$ concentrations involves a trial-and-error approach, but the effort is mitigated by the fact that warming is a roughly linear function of $\mathrm{CO}_{2}$ (for small amounts of warming) and the model reaches steady state in 5-10 years. There are no changes to the temperature or salinity corrections, which assumes that the mean ocean heat and salt transports do not change for relatively small warming. However, we impose changes to sea ice and the prescribed SSTs in uncoupled (seasonally ice-covered) regions. We compute these using a transient simulation of the fully coupled MetUM-GC2 (Williams et al., 2015) with a $1 \% \mathrm{yr}^{-1} \mathrm{CO}_{2}$ increase, by averaging 20 year periods with global-mean warming closest to our 0.98 and $1.48^{\circ} \mathrm{C}$ target levels and taking the difference between these periods and the climatology of the MetUM-GC2 present-day control simulation. We apply these differences to the 1976-2005 observed climatologies.

Thirdly, we perform initial condition perturbation ensembles of MetUM-GOML2 simulations at the target warming levels, using the $\mathrm{CO}_{2}$ concentrations and sea ice and highlatitude SST boundary conditions determined above. Finally, we perform AMIP-type experiments with the same atmospheric model, in which we prescribe the daily SSTs and sea ice from the MetUM-GOML2 ensembles. MetUM-GOML2 uses a $3 \mathrm{~h}$ coupling frequency; converting to daily SSTs introduces sufficient noise to cause the coupled and atmosphereonly experiments to diverge. 
Comparing the coupled and AMIP-type experiments at the same level of warming allows one to determine the sensitivity of the response to the presence of atmosphere-ocean interactions, in a framework in which the mean and interannual variability of SST and sea ice are consistent between the simulations. Similarly, comparing the relative difference between the 1.5 and $2.0^{\circ} \mathrm{C}$ simulations in the coupled and AMIP-type experiments allows one to determine whether the response to an additional half-degree of warming is sensitive to inclusion of air-sea coupled feedbacks. We expect that analysis of these experiments will focus mainly on subseasonal variability and extremes (e.g. heatwaves, intense precipitation events), but it is possible that air-sea coupling will also affect the mean response.

\section{Toward understanding impacts}

Assessing potential impacts of 1.5 and $2{ }^{\circ} \mathrm{C}$ of warming goes beyond climate scenarios and requires integrated impact model projections. HAPPI therefore cooperates with the Inter-Sectoral Impact Model Intercomparison Project (ISIMIP, Warszawski et al., 2013b) range of sectors including agriculture and agro-economic modelling (Rosenzweig et al., 2013; Elliot et al., 2013), water (Schewe et al., 2014), biomes and forestry (Warszawski et al., 2013a), permafrost, and human health (Mitchell et al., 2016a). To allow for the HAPPI modelling effort to be most useful for the impact community, the HAPPI diagnostics provided resemble the climate model input required for the ISIMIP modelling protocol.

Specifically, a priority subset of HAPPI AGCM output will be provided in bias-corrected format following the ISIMIP2 $b$ bias correction approach (Frieler et al., 2016). A sectorspecific modelling protocol will be available following the ISIMIP2b simulation protocol including socio-economic and management options.

\section{Summary}

HAPPI has been developed to explicitly inform one of the primary aims of the Paris Agreement, which seeks to understand impacts of a world limiting global-averaged warming to $1.5^{\circ} \mathrm{C}$. It provides climate data for analysis of a range of impacts under current, 1.5 and $2{ }^{\circ} \mathrm{C}$ climate scenarios. The high number of ensemble members $(>50)$ allow for information on policy-relevant timescales to be assessed, while the 10 year length of the simulations also allows for longlived extremes, such as droughts, to be characterized. The two tiers of experiments provide an assessment of not only the desired climate change scenario, but also the uncertainties in how we developed the scenario, most notably through sensitivity tests in the SSTs and sea ice conditions. The data are available in bias-corrected or raw formats, and are ready for direct input to a range of common climate-impact models.

\section{Data availability}

Data published on the portal will be compliant with a modified version of the $\mathrm{C} 20 \mathrm{C}+\mathrm{D} \& \mathrm{~A}$ conventions. All raw data will be available, as well as a bias-corrected ISIMIP subset using the Frieler et al. (2016) methodology.

Output from all HAPPI and associated experiments are to be published through the joint $\mathrm{C} 20 \mathrm{C}+\mathrm{D} \& \mathrm{~A}$ project-HAPPI portal, hosted by the National Energy Research Scientific Computing center (NERSC) at http://portal.nersc.gov/c20c/ data.html. The HAPPI data policy uses the same principles as the Coupled Chemistry Model Validation (CCMVal) policy. The HAPPI data are therefore made available to all researchers outside the HAPPI community, provided that they become official HAPPI collaborators. All collaborators are asked to respect the interests of the HAPPI community, and are therefore encouraged to keep lines of communication open throughout any analysis. Publications of HAPPI data and corresponding scientific analysis are encouraged, and the data policy involves two phases in line with CCMVal. Phase 1 runs up to the cut-off date for publications to be included in the IPCC Special Report (in April 2018). During this phase users are obligated to offer co-authorship to the HAPPI core team, and to acknowledge NERSC for data storage. Phase 2 follows publication of the IPCC Special Report, and requires acknowledgment of the HAPPI core team and NERSC. During the latter phase it is intended that HAPPI data will be used to inform AR6 among other initiatives, and may well include high-temperature scenarios, such as $3{ }^{\circ} \mathrm{C}$.

HAPPI website: The project is kept up-to-date with news, collaborations, publications and experiments at http: //happimip.org. 


\section{Appendix A}

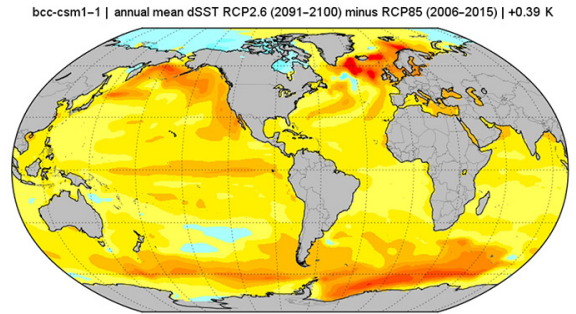

CESM1-CAM5 (3) | annual mean dSST RCP2.6 (2091-2100) minus RCP85 (2006-2015) |+0.81 K

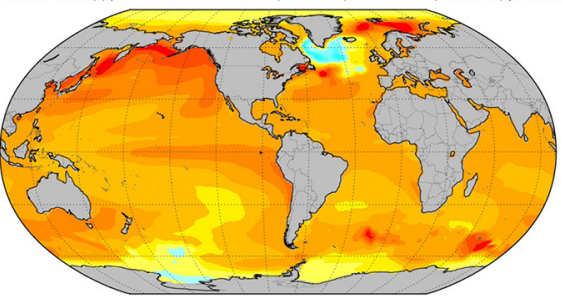

CNRM-CM5 | annual mean dSST RCP2.6 (2091-2100) minus RCP85 (2006-2015) | +0.51 K

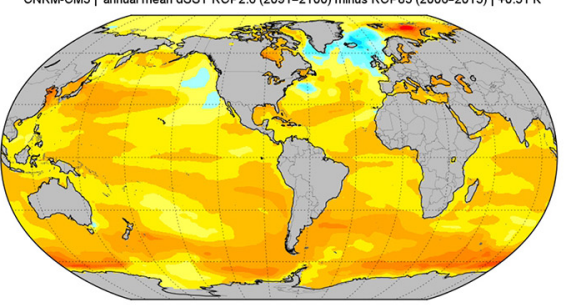

GFDL-ESM2G | annual mean dSST RCP2.6 (2091-2100) minus RCP85 (2006-2015) |-0.01 K

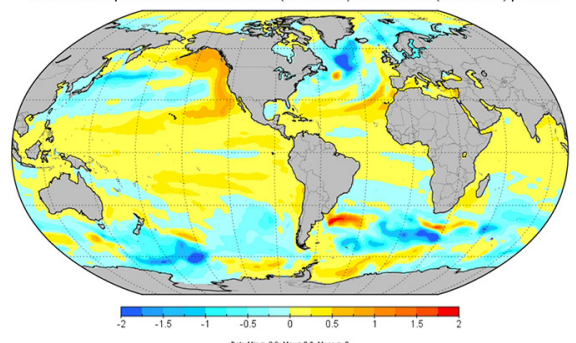

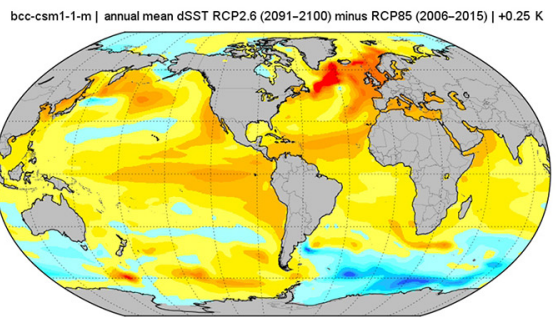

CCSM4 (6) | annual mean dSST RCP2.6 (2091-2100) minus RCP85 (2006-2015) | +0.32 K

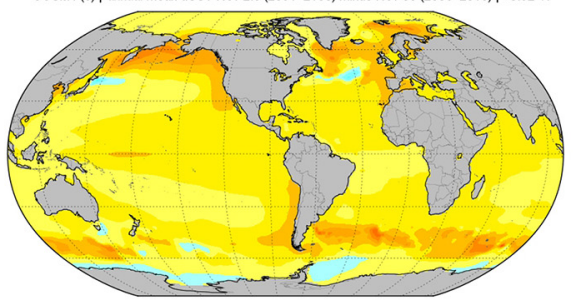

EC-EARTH | annual mean dSST RCP2.6 (2091-2100) minus RCP85 (2006-2015) | +0.37 K

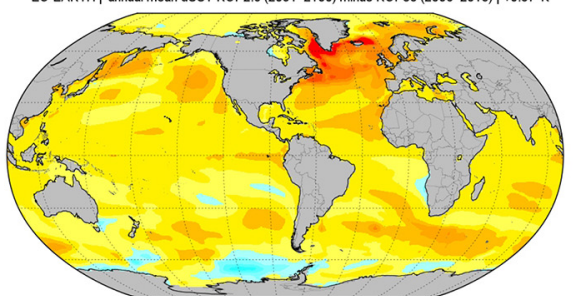

GFDL-ESM2M | annual mean dSST RCP2.6 (2091-2100) minus RCP85 (2006-2015) | +0.31 K

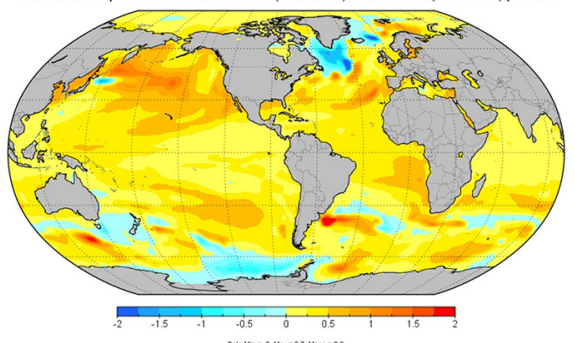

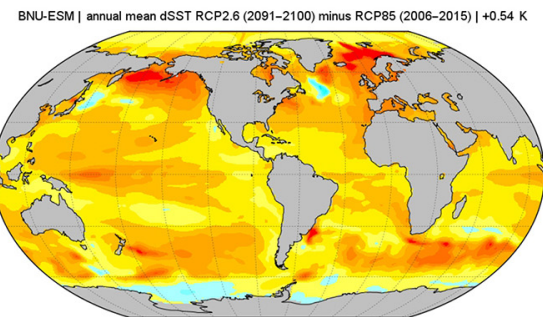

CanESM2 (5) | annual mean dSST RCP2.6 (2091-2100) minus RCP85 (2006-2015) | +0.62 K

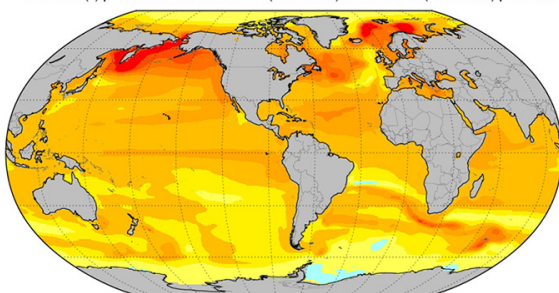

GFDL-CM3 | annual mean dSST RCP2.6 (2091-2100) minus RCP85 (2006-2015) |+1.02 K

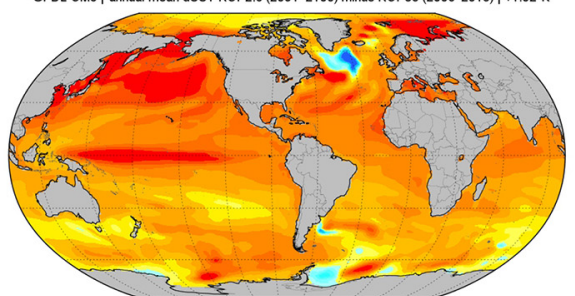

GISS-E2-HI annual mean dSST RCP2.6 (2091-2100) minus RCP85 (2006-2015) | +0.27 K

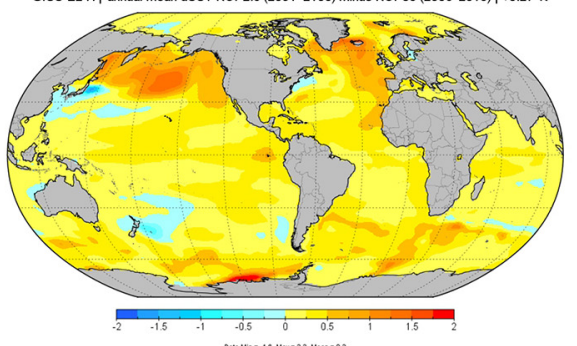

Figure A1. As in the $1.5^{\circ}$ experiment delta SST pattern in Fig. 3 but for the first set of 12 individual models. 

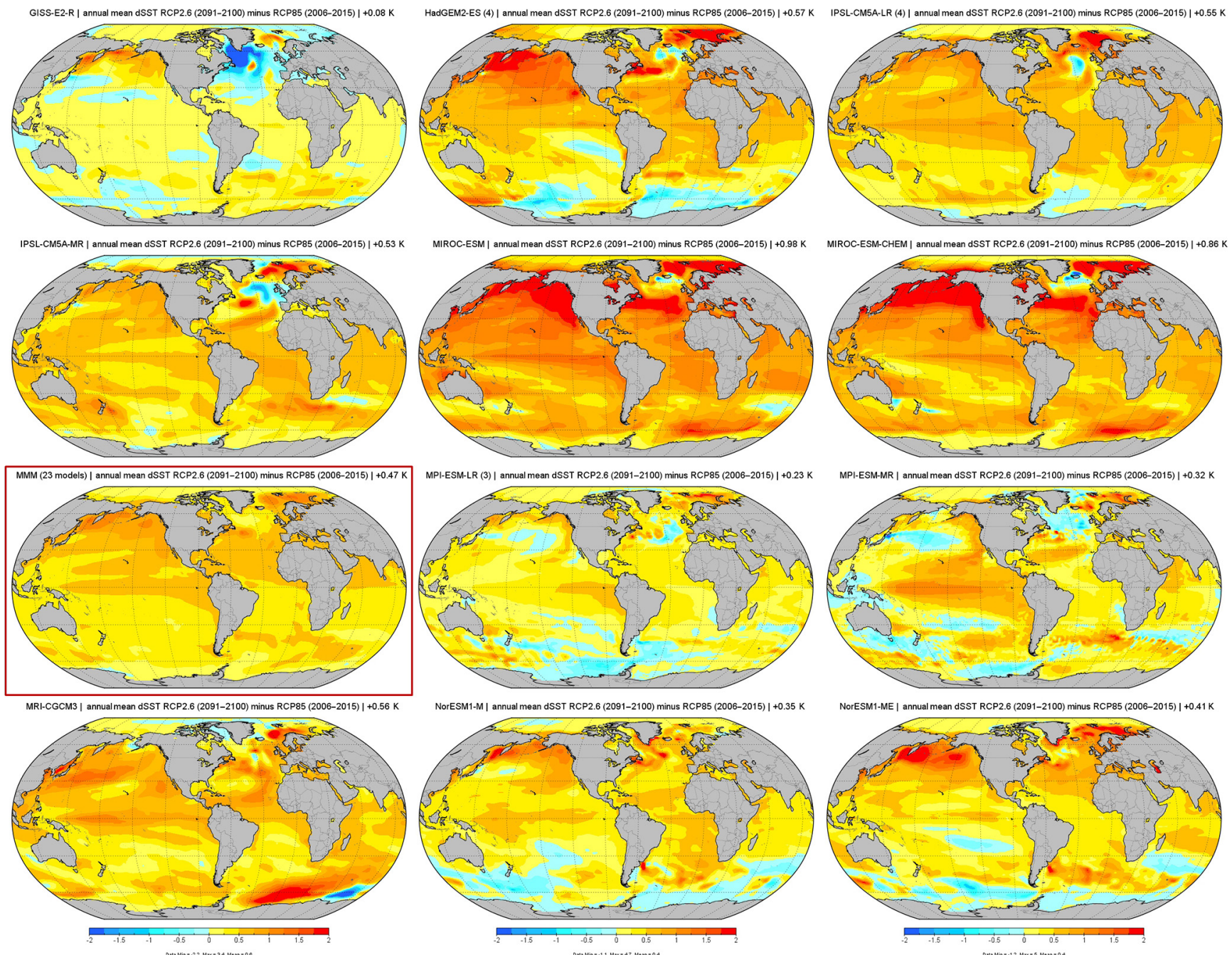

Figure A2. As previous but for the second set of 12 individual models. 
Acknowledgements. We would like to thank Ben Sanderson, Reto Knutti and Annette Hirsch for their in-depth reviews of our paper. Daniel Mitchell received support from the NERC ACE Africa and a NERC Independent Research Fellowship (NE/N014057/1). Jan Fuglestvedt, Ingo Bethke, Trond Iversen and Øyvind Seland received support from the Research Council of Norway, project no. 261821. This material involved work supported by the US Department of Energy, Office of Science, Office of Biological and Environmental Research, under contract number DE-AC0205CH11231. Hideo Shiogama was supported by the Program for Risk Information on Climate Change from the Ministry of Education, Culture, Sports, Science and Technology of Japan, and by the Environment Research and Technology Development Fund (S-10) of the Ministry of the Environment of Japan. Carl-Friedrich Schleussner was supported by the German Federal Ministry for the Environment, Nature Conservation and Nuclear Safety (11_II_093_Global_A_SIDS and LDCs). Nicholas Klingaman was funded by an Independent Research Fellowship from the UK Natural Environment Research Council (NE/L010976/1).

Edited by: D. Lawrence

Reviewed by: B. Sanderson and R. Knutti

\section{References}

Anderson, K. and Nevins, J.: Planting Seeds So Something Bigger Might Emerge: The Paris Agreement and the Fight Against Climate Change, Socialism and Democracy, 30, 209-218, 2016.

AR3: Concentration to radiative forcing relationships, Climate Change 2001: The Scientific Basis, Working Group I: The Scientific Basis, http://www.grida.no/publications/other/ipcc_tar/ ?src=/climate/ipcc_tar/wg1/, 2001.

Bentsen, M., Bethke, I., Debernard, J. B., Iversen, T., Kirkevåg, A., Seland, Ø., Drange, H., Roelandt, C., Seierstad, I. A., Hoose, C., and Kristjánsson, J. E.: The Norwegian Earth System Model, NorESM1-M - Part 1: Description and basic evaluation of the physical climate, Geosci. Model Dev., 6, 687-720, doi:10.5194/gmd-6-687-2013, 2013.

Boucher, O., Bellassen, V., Benveniste, H., Ciais, P., Criqui, P., Guivarch, C., Le Treut, H., Mathy, S., and Séférian, R.: Opinion: In the wake of Paris Agreement, scientists must embrace new directions for climate change research, P. Natl. Acad. Sci. USA, 113, 7287-7290, 2016.

Collins, M., Knutti, R., Arblaster, J., Dufresne, J.-L., Fichefet, T., Friedlingstein, P., Gao, X., Gutowski, W. J., Johns, T., Krinner, G., Shongwe, M., Tebaldi, C., Weaver, A. J., and Wehner, M.: Long-term Climate Change: Projections, Commitments and Irreversibility, in: Climate Change 2013: The Physical Science Basis, Contribution of Working Group I to the Fifth Assessment Report of the Intergovernmental Panel on Climate Change, edited by: Stocker, T. F., Qin, D., Plattner, G.-K., Tignor, M., Allen, S. K., Boschung, J., Nauels, A., Xia, Y., Bex, V., and Midgley, P. M., Cambridge University Press, Cambridge, UK, New York, NY, USA, 2013.

DeMott, C. A., Klingaman, N. P., and Woolnough, S. J.: Atmosphere-ocean coupled processes in the Madden-Julian oscillation, Rev. Geophys., 53, 1099-1154, 2015.
Elliott, J., Deryng, D., Müller, C., Frieler, K., Konzmann, M., Gerten, D., Glotter, M., Flörke, M., Wada, Y., Best, N., Eisner, S., Fekete, B. M., Folberth, C., Foster, I., Gosling, S. N., Haddeland, I., Khabarov, N., Ludwig, F., Masaki, Y., Olin, S., Rosenzweig, C., Ruane, A. C., Satoh, Y., Schmid, E., Stacke, T., Tang, Q., and Wisser, D.: Constraints and potentials of future irrigation water availability on agricultural production under climate change, P. Natl. Acad. Sci. USA, 111, 3239-3244, doi:10.1073/pnas.1222474110, 2013.

Fischer, E. and Knutti, R.: Anthropogenic contribution to global occurrence of heavy-precipitation and high-temperature extremes, Nat. Clim. Change, 2015.

Folland, C., Stone, D., Frederiksen, C., Karoly, D., and Kinter, J.: The international CLIVAR Climate of the 20th Century Plus $(\mathrm{C} 20 \mathrm{C}+)$ Project: Report of the sixth workshop, CLIVAR Exchange, 19, 57-59, 2014.

Frieler, K., Betts, R., Burke, E., Ciais, P., Denvil, S., Deryng, D., Ebi, K., Eddy, T., Emanuel, K., Elliott, J., Galbraith, E., Gosling, S. N., Halladay, K., Hattermann, F., Hickler, T., Hinkel, J., Huber, V., Jones, C., Krysanova, V., Lange, S., Lotze, H. K., LotzeCampen, H., Mengel, M., Mouratiadou, I., Müller Schmied, H., Ostberg, S., Piontek, F., Popp, A., Reyer, C. P. O., Schewe, J., Stevanovic, M., Suzuki, T., Thonicke, K., Tian, H., Tittensor, D. P., Vautard, R., van Vliet, M., Warszawski, L., and Zhao, F.: Assessing the impacts of $1.5^{\circ} \mathrm{C}$ global warming - simulation protocol of the Inter-Sectoral Impact Model Intercomparison Project (ISIMIP2b), Geosci. Model Dev. Discuss., doi:10.5194/gmd2016-229, in review, 2016.

Gillett, N. P., Shiogama, H., Funke, B., Hegerl, G., Knutti, R., Matthes, K., Santer, B. D., Stone, D., and Tebaldi, C.: The Detection and Attribution Model Intercomparison Project (DAMIP v1.0) contribution to CMIP6, Geosci. Model Dev., 9, 3685-3697, doi:10.5194/gmd-9-3685-2016, 2016.

He, J. and Soden, B. J.: The Impact of SST Biases on Projections of Anthropogenic Climate Change: A Greater Role for Atmosphere-only Models?, Geophys. Res. Lett., 43, 7745-7750, 2016.

Hirons, L. C., Klingaman, N. P., and Woolnough, S. J.: MetUMGOML1: a near-globally coupled atmosphere-ocean-mixedlayer model, Geosci. Model Dev., 8, 363-379, doi:10.5194/gmd8-363-2015, 2015.

Hulme, M.: $1.5^{\circ} \mathrm{C}$ and climate research after the Paris Agreement, Nat. Clim. Change, 6, 222-224, 2016.

Iversen, T., Bentsen, M., Bethke, I., Debernard, J. B., Kirkevåg, A., Seland, Ø., Drange, H., Kristjansson, J. E., Medhaug, I., Sand, M., and Seierstad, I. A.: The Norwegian Earth System Model, NorESM1-M - Part 2: Climate response and scenario projections, Geosci. Model Dev., 6, 389-415, doi:10.5194/gmd-6-3892013, 2013.

James, R., Washington, R., Schleussner, C.-F., Rogelj, J., and Conway, D.: Characterizing half-a-degree difference: a review of methods for identifying regional climate responses to global warming targets, WIREs Clim Change, doi:10.1002/wcc.457, online first, 2017.

Kirkevåg, A., Iversen, T., Seland, Ø., Hoose, C., Kristjánsson, J. E., Struthers, H., Ekman, A. M. L., Ghan, S., Griesfeller, J., Nilsson, E. D., and Schulz, M.: Aerosol-climate interactions in the Norwegian Earth System Model - NorESM1-M, Geosci. Model Dev., 6, 207-244, doi:10.5194/gmd-6-207-2013, 2013. 
Massey, N.: Generating sea ice patterns and uncertainity from coupled climate models, J. Geophys. Res., in preparation, 2017.

Massey, N., Jones, R., Otto, F., Aina, T., Wilson, S., Murphy, J., Hassell, D., Yamazaki, Y., and Allen, M.: weather@homedevelopment and validation of a very large ensemble modelling system for probabilistic event attribution, Q. J. Roy. Meteor. Soc., 141, 1528-1545, 2014.

Mitchell, D., Heaviside, C., Vardoulakis, S., Huntingford, C., Masato, G., Guillod, B. P., Frumhoff, P., Bowery, A., Wallom, D., and Allen, M.: Attributing human mortality during extreme heat waves to anthropogenic climate change, Environ. Res. Lett., 11, 074006, http://stacks.iop.org/1748-9326/11/i=7/ $\mathrm{a}=074006,2016 \mathrm{a}$.

Mitchell, D., James, R., Forster, P., Betts, R., Shiogama, H., and Allen, M.: Realizing the impacts of a $1.5^{\circ} \mathrm{C}$ warmer world., Nat. Clim. Change, 6, 735-737, doi:10.1038/nclimate3055, 2016b.

Nakicenovic, N. and Swart, R.: Special report on emissions scenarios, Special Report on Emissions Scenarios, edited by: Nakicenovic, N. and Swart, R., Cambridge University Press, Cambridge, UK, 612 pp., ISBN 0521804930, 2000.

Neale, R. B., Chen, C. C., Gettelman, A., Lauritzen, P. H., Park, S., Williamson, D. L., Conley, A. J., Garcia, R., Kinnison, D., Lamarque, J. F., and Marsh, D.: Description of the NCAR community atmosphere model (CAM 5.0), NCAR Tech. Note NCAR/TN-486+ STR, 2010.

Neale, R. B., Richter, J., Park, S., Lauritzen, P. H., Vavrus, S. J., Rasch, P. J., and Zhang, M.: The mean climate of the Community Atmosphere Model (CAM4) in forced SST and fully coupled experiments, J. Climate, 26, 5150-5168, 2013.

Peters, G. P.: The "best available science" to inform $1.5^{\circ} \mathrm{C}$ policy choices, Nat. Clim. Change, 6, 646-649, doi:10.1038/nclimate3000, 2016.

Richardson, M., Cowtan, K., Hawkins, E., and Stolpe, M. B.: Reconciled climate response estimates from climate models and the energy budget of Earth, Nat. Clim. Change, 6, 931-935, doi:10.1038/nclimate3066, 2016.

Rogelj, J. and Knutti, R.: Geosciences after Paris, Nat. Geosci., 9, 187-189, 2016.

Rosenzweig, C., Elliott, J., Deryng, D., Ruane, A. C., Müller, C., Arneth, A., Boote, K. J., Folberth, C., Glotter, M., Khabarov, N., Neumann, K., Piontek, F., Pugh, T. a. M., Schmid, E., Stehfest, E., Yang, H., and Jones, J. W.: Assessing agricultural risks of climate change in the 21 st century in a global gridded crop model intercomparison, P. Natl. Acad. Sci. USA, 111, 32683273, doi:10.1073/pnas.1222463110, 2013.

Schewe, J., Heinke, J., Gerten, D., Haddeland, I., Arnell, N. W., Clark, D. B., Dankers, R., Eisner, S., Fekete, B. M., ColonGonzalez, F. J., Gosling, S. N., Kim, H., Liu, X., Masaki, Y., Portmann, F. T., Satoh, Y., Stacke, T., Tang, Q., Wada, Y., Wisser, D., Albrecht, T., Frieler, K., Piontek, F., Warszawski, L., and Kabat, P.: Multimodel assessment of water scarcity under climate change, P. Natl. Acad. Sci. USA, 111, 3245-3250, doi:10.1073/pnas.1222460110, 2014.

Schleussner, C.-F., Lissner, T. K., Fischer, E. M., Wohland, J., Perrette, M., Golly, A., Rogelj, J., Childers, K., Schewe, J., Frieler, K., Mengel, M., Hare, W., and Schaeffer, M.: Differential climate impacts for policy-relevant limits to global warming: the case of $1.5^{\circ} \mathrm{C}$ and $2^{\circ} \mathrm{C}$, Earth Syst. Dynam., 7, 327-351, doi:10.5194/esd-7-327-2016, 2016.
Schleussner, C.-F., Rogelj, J., Schaeffer, M., Lissner, T., Licker, R., Fischer, E. M., Knutti, R., Levermann, A., Frieler, K., and Hare, W.: Science and policy characteristics of the Paris Agreement temperature goal, Nat. Clim. Change, 6, 827-835, doi:10.1038/nclimate3096, 2016.

Shiogama, H., Watanabe, M., Imada, Y., Mori, M., Kamae, Y., Ishii, M., and Kimoto, M.: Attribution of the June-July 2013 heat wave in the southwestern United States, SOLA, 10, 122-126, 2014.

Smith, D. M. and Murphy, J. M.: An objective ocean temperature and salinity analysis using covariances from a global climate model, J. Geophys. Res.-Oceans, 112, C02022, doi:10.1029/2005JC003172, 2007.

Son, S., Gerber, E., Perlwitz, J., Polvani, L., Gillett, N., Seo, K., Eyring, V., Shepherd, T., Waugh, D., Akiyoshi, H., Austin, J., Baumgaertner, A., Bekki, S., Braesicke, P., Brühl, C., Butchart, N., Chipperfield, M. P., Cugnet, D., Dameris, M., Dhomse, S., Frith, S., Garny, H., Garcia, R., Hardiman, S. C., Jöckel, P., Lamarque, J. F., Mancini, E., Marchand, M., Michou, M., Nakamura, T., Morgenstern, O., Pitari, G., Plummer, D. A., Pyle, J., Rozanov, E., Scinocca, J. F., Shibata, K., Smale, D., Teyssèdre, H., Tian, W., and Yamashita, Y.: Impact of stratospheric ozone on Southern Hemisphere circulation change: A multimodel assessment, J. Geophys. Res, 115, D00M07, doi:10.1029/2010JD014271, 2010.

Stark, J. D., Donlon, C. J., Martin, M. J., and McCulloch, M. E.: OSTIA: An operational, high resolution, real time, global sea surface temperature analysis system, in: Oceans 2007-Europe, $1-4,2007$.

Taylor, K. E., Stouffer, R. J., and Meehl, G. A.: An overview of CMIP5 and the experiment design, B. Am. Meteorol. Soc., 93, 485-498, doi:10.1175/BAMS-D-11-00094.1, 2012.

Turner, J., Bracegirdle, T. J., Phillips, T., Marshall, G. J., and Hosking, J. S.: An initial assessment of Antarctic sea ice extent in the CMIP5 models, J. Climate, 26, 1473-1484, 2013.

United Nations Framework Convention on Climate Change (UNFCCC): Adoption of the Paris Agreement, Conference of the Parties, Paris, France, 30 November-11 December, 2015.

Van Vuuren, D. P., Edmonds, J., Kainuma, M., Riahi, K., Thomson, A., Hibbard, K., Hurtt, G. C., Kram, T., Krey, V., Lamarque, J. F., and Masui, T.: The representative concentration pathways: an overview, Clim. Change, 109, 5-31, 2011.

von Salzen, K., Scinocca, J. F., McFarlane, N. A., Li, J., Cole, J. N., Plummer, D., Verseghy, D., Reader, M. C., Ma, X., Lazare, M., and Solheim, L.: The Canadian fourth generation atmospheric global climate model (CanAM4) - Part I: representation of physical processes, Atmos. Ocean, 51, 104-125, 2013.

Walters, D., Brooks, M., Boutle, I., Melvin, T., Stratton, R., Vosper, S., Wells, H., Williams, K., Wood, N., Allen, T., Bushell, A., Copsey, D., Earnshaw, P., Edwards, J., Gross, M., Hardiman, S., Harris, C., Heming, J., Klingaman, N., Levine, R., Manners, J., Martin, G., Milton, S., Mittermaier, M., Morcrette, C., Riddick, T., Roberts, M., Sanchez, C., Selwood, P., Stirling, A., Smith, C., Suri, D., Tennant, W., Vidale, P. L., Wilkinson, J., Willett, M., Woolnough, S., and Xavier, P.: The Met Office Unified Model Global Atmosphere 6.0/6.1 and JULES Global Land 6.0/6.1 configurations, Geosci. Model Dev. Discuss., doi:10.5194/gmd2016-194, in review, 2016.

Warszawski, L., Frieler, K., Huber, V., Piontek, F., Serdeczny, O., and Schewe, J.: The Inter-Sectoral Impact Model Intercompar- 
ison Project (ISI-MIP): Project framework, P. Natl. Acad. Sci. USA, 111, 3228-3232, doi:10.1073/pnas.1312330110, 2013a.

Warszawski, L., Friend, A., Ostberg, S., Frieler, K., Lucht, W., Schaphoff, S., Beerling, D., Cadule, P., Ciais, P., Clark, D. B., Kahana, R., Ito, A., Keribin, R., Kleidon, A., Lomas, M., Nishina, K., Pavlick, R., Rademacher, T. T., Buechner, M., Piontek, F., Schewe, J., Serdeczny, O., and Schellnhuber, H. J.: A multi-model analysis of risk of ecosystem shifts under climate change, Environ. Res. Lett., 8, 044018, doi:10.1088/17489326/8/4/044018, 2013b.

Wehner, M. F., Reed, K. A., Li, F., Bacmeister, J., Chen, C. T., Paciorek, C., Gleckler, P. J., Sperber, K. R., Collins, W. D., Gettelman, A., and Jablonowski, C: The effect of horizontal resolution on simulation quality in the Community Atmospheric Model, CAM5. 1, J. Adv. Model. Earth Sys., 6, 980-997, 2014.
Williams, K. D., Harris, C. M., Bodas-Salcedo, A., Camp, J., Comer, R. E., Copsey, D., Fereday, D., Graham, T., Hill, R., Hinton, T., Hyder, P., Ineson, S., Masato, G., Milton, S. F., Roberts, M. J., Rowell, D. P., Sanchez, C., Shelly, A., Sinha, B., Walters, D. N., West, A., Woollings, T., and Xavier, P. K.: The Met Office Global Coupled model 2.0 (GC2) configuration, Geosci. Model Dev., 8, 1509-1524, doi:10.5194/gmd-8-1509-2015, 2015. 